\title{
DINAMIKA TETES EKSTRAKSI CAIR-CAIR SISTEM AIR-METIL ETIL KETON (MEK)-HEKSAN DALAM KOLOM ISIAN
}

\author{
Agus Mirwan*1 dan Danu Ariono² \\ 1 Program Studi Teknik Kimia, Fakultas Teknik, Universitas Lambung Mangkurat \\ Jalan Jend. A. Yani Km.36 Banjarbaru 70714 \\ ${ }^{2}$ Program Studi Teknik Kimia, Fakultas Teknologi Industri, \\ Institut Teknologi Bandung, Jalan Ganesha 10 Bandung 40132 \\ Email: agusmirwan@yahoo.com
}

\begin{abstract}
Abstrak
Proses perpindahan massa ekstraksi cair-cair dalam kolom isian terjadi akibat adanya kontak antara fase kontinu dan fase dispersi yang dialirkan secara berlawanan. Berbagai macam ukuran dan jenis isian yang digunakan dalam kolom, menyebabkan luas permukaan kontak menjadi lebih besar dan waktu kontak makin lama sehingga terjadi peningkatan proses perpindahan massa. Penelitian ini bertujuan mengamati dinamika pergerakan tetesan dengan cara mengelompokkan ukuran diameter tetesan berdasarkan pada rezim aliran yang diwakilkan dengan Bilangan Reynold $(R e)$ dan mempelajari perpindahan massa pada ekstrasi cair-cair dalam kolom isian yang didasarkan ukuran diameter tetesan yang dipengaruhi laju alir dan jenis isian. Pengamatan perilaku tetesan dilakukan dengan menggunakan kolom persegi panjang yang transparan sehingga secara visual dinamikanya dapat diamati dan direkam pada tiap segmen ketinggian kolom menggunakan kamera digital. Percobaan dilakukan dengan menggunakan sistem air-MEK (metil etil keton)-n-heksan. Hasil penelitian untuk jenis isian bola padat dan raschig ring menunjukkan bahwa makin besar laju alir fase dispersi dan ketinggian dari bagian bawah (distributor), maka tetesannya makin kecil dengan jumlah yang makin banyak. Hal ini menyebabkan kenaikan yang signifikan terhadap koefisien perpindahan massa keseluruhan.
\end{abstract}

Kata kunci: distribusi tetesan, bola, raschig ring, diameter tetesan.

\begin{abstract}
Mass transfer process occurs as effect of contact between continuous phase from above and dispersed phase from underside column. With existence of size and type of packing in column, that caused interfacial area to become bigger and residence time more and older so that improvement of mass transfer process. The aim of this research is to observe drop dynamics or movement behavior of drop in which the drop diameter size grouped based on current regime deputizing with Reynolds Number $(R e)$ and to study mass transfer liquidliquid extraction in packed column based on drop diameter size influenced by flow rate and packing type. Observation of drop behavior is done by using length square column transparent so that visually drop dynamics can be observed and recorded at every segment of column height using digital camera. This research will be done by varying packing type and flow rate of the dispersed phase and continuous phase to know behavior of drop. The research will be done by using water-MEK (methyl ethyl ketone)-n-hexane system. The result of this research for packing type of sphere and raschig ring show that more and more big dispersed phase flow rate and height from under side column (distributor), hence drop is more and more small with number of which more and more many. This caused significant increase on overall mass transfer coefficient.
\end{abstract}

Keywords: drop distribution, sphere, raschig ring, drop diameter.

*korespondensi 


\section{Pendahuluan}

Salah satu proses pemisahan yang terkenal dan banyak digunakan dalam industri kimia adalah proses ekstraksi. Proses ekstraksi merupakan metode pemisahan campuran yang didasarkan atas perbedaan kelarutan suatu solut dalam pelarut. Ekstraksi solvent atau yang lebih dikenal dengan ekstraksi cair-cair merupakan proses pemisahan fase cair yang memanfaatkan perbedaan kelarutan zat yang akan dipisahkan antara larutan asal dan pelarut pengekstrak (solvent) (Laddha dan Degaleesan, 1976). Prinsip dasar dari ekstraksi cair-cair ini melibatkan pengontakan suatu larutan dengan pelarut (solvent) lain yang tidak saling melarut (immisible) dengan pelarut asal yang mempunyai densitas yang berbeda sehingga akan terbentuk dua fase beberapa saat setelah penambahan solvent (Ariono dkk., 2006). Hal ini menyebabkan terjadinya perpindahan massa dari pelarut asal ke pelarut pengekstrak (solvent).

Sebagai unit operasi pemisahan alternatif disamping distilasi dan adsorbsi, ekstraksi cair-cair ini pada kondisi tertentu memiliki beberapa kelebihan diantaranya dapat beroperasi pada kondisi ruang, dapat memisahkan sistem yang memiliki sensitivitas terhadap temperatur, dapat memisahkan sistem dengan perbedaan titik didih relatif kecil dan kebutuhan energinya juga relatif kecil (Nababan, 2006; Ariono dkk., 2008). Aplikasi ekstraksi cair-cair ini telah banyak digunakan pada sektor industri diantaranya pada pemprosesan kembali bahan bakar nuklir, pemisahan logam-logam, pemisahan senyawa-senyawa aromatik pada industri petroleum, industri obat-obatan, petrokimia, pengolahan air limbah industri, hydrometallurgy dan industri makanan (Mirwan dan Ariono, 2009).

Pada proses pemisahan ekstraksi caircair yang terjadi dalam kolom isian, larutan umpan sebagai fase kontinu dialirkan dari bagian atas kolom. Sedangkan pelarut pengekstrak sebagai fase dispersi dialirkan dari bagian bawah kolom. Karena adanya perbedaan densitas di kedua cairan tersebut serta kedua cairan tidak saling melarut, maka salah satu cairan dapat membentuk tetesan dalam cairan lainnya sehingga terjadi kontak yang intim antara kedua cairan tersebut. Tetesan yang bergerak naik di dalam kolom dapat mengalami peristiwa perpecahan dan/atau penggabungan antar tetesan.
Peristiwa perpecahan terjadi akibat tetesan tersebut menabrak isian yang berada didalam kolom. Pecahnya tetesan dalam kolom sangat menguntungkan karena dapat meningkatkan luas bidang kontak antar cairan serta memperbesar waktu kontak antara kedua cairan dalam kolom (Mirwan dan Ariono, 2009; Putranto, 2004).

Beberapa kemungkinan perilaku tetesan yang terjadi dalam kolom isian diantaranya adalah tetesan bergerak tanpa halangan melewati celah isian; tetesan bergabung dengan bagian isian dan pecah menjadi dua tetesan yang lebih kecil; tetesan bergabung dengan bagian isian tanpa disertai dengan pecahnya tetesan; tetesan terdistorsi pada saat melewati celah isian dan tetesan terjebak pada celah isian dan bergabung dengan tetesan berikutnya (Putranto, 2004). Dengan demikian ukuran tetes akan mengalami perubahan pada saat tetesan bergerak disela-sela bahan isian disepanjang kolom. Perubahan ukuran tetesan senantiasa akan diikuti dengan perubahan jumlah tetesan pada ukuran tersebut. Perubahan ukuran dan jumlah tetesan menyebabkan luas kontak perpindahan massa antara fase kontinu dan fase dispersi berubah. Sehingga pada gilirannya akan menyebabkan perubahan harga koefisien perpindahan massanya (Ariono dan Mirwan, 2008; Mirwan dan Ariono, 2009; Putranto, 2004).

Adanya isian menyebabkan perpindahan massa meningkat 2 sampai 3 kali bila dibandingkan dengan perpindahan massa dalam kolom kosong, misalnya kolom semprot; sifat sistem yang digunakan mempunyai pengaruh yang signifikan dan diameter tetesan merupakan fungsi laju alir dan jenis isian (Seibert dan Fair, 1988). Hal ini juga didukung oleh pernyataan Hashem dan El-Bassuoni (2007) bahwa ukuran tetes yang kecil dan laju fase dispersi dan fase kontinu memberikan pengaruh yang signifikan terhadap perpindahan massa. Makalah ini menjelaskan perilaku tetes dalam kolom isian yang ditampilkan dalam bentuk kurva distribusi ukuran tetesan di sepanjang kolom isian pada berbagai laju alir fase dispersi, fase kontinu dan jenis isian serta koefisien perpindahan massa keseluruhan terhadap diameter rata-rata tetes.

\section{Metodologi}

Pengamatan untuk mempelajari perilaku/dinamika tetesan dilakukan dalam kolom berpenampang persegi panjang 
$(4,5 \times 10 \mathrm{~cm})$ yang tembus pandang. Model campuran yang digunakan adalah air-metil etil keton (MEK)-n-heksan, dimana MEK sebagai solut mula-mula berada dalam air kemudian diekstraksi dengan pelarut $\mathrm{n}$ heksan. Dua jenis isian yang digunakan ialah bola padat berdiameter $1 \mathrm{~cm}$ dan raschig ring berukuran $1 \times 1 \mathrm{~cm}$ setinggi $60 \mathrm{~cm}$. Pengamatan dilakukan pada tiga laju alir fase dispersi, yaitu 0,14 mL/detik (Qd-1), 2,00 $\mathrm{mL} /$ detik (Qd-2), dan 4,27 mL/detik (Qd-3). Fase kontinu dilakukan juga tiga laju alir yaitu: $2,67 \mathrm{~mL} /$ detik (Qc-1), 12,33 $\mathrm{mL} /$ detik (Qc-2) dan 22,67 mL/detik (Qc-3). Umpan yang diekstraksi mengandung MEK yang konsentrasinya $2 \mathrm{M}$. Pengamatan dinamika tetes dalam kolom isian dilakukan secara visual dan direkam dengan menggunakan alat bantu perekam gambar berupa kamera digital. Pengamatan dinamika tetes dilakukan dengan membagi kolom dalam berbagai segmen ketinggian. Kolom dibagi menjadi enam segmen ketinggian, masing-masing segmen tingginya $10 \mathrm{~cm}$. Hal ini dilakukan untuk mengetahui perubahan dinamika tetes dalam kolom (lihat Gambar 1).

Hasil rekaman gambar tetesan yang diperoleh kemudian dilakukan perhitungan jumlah dan ukuran atau diameter tetes dengan metoda yang dikembangkan oleh (Hamilton, 1984). Metode tersebut adalah menggunakan skala milimeter yang diletakkan pada bagian tertentu di kolom. Dalam eksperimen ini, perhitungan dilakukan dengan cara meletakkan grid skala milimeter pada gambar digital.

Tetesan yang diamati dihitung luasannya kemudian dikonversikan ke bentuk bola yang proyeksinya memiliki luas yang sama dengan luasan tetesan yang teramati. Kemudian tetesan tersebut dikelompokan berdasarkan rentang diameter tetesan berikut: kelompok d0 berdiameter $<0,5 \mathrm{~mm}$; d1 berdiameter 0,5-1,49 $\mathrm{mm}$; d2 berdiameter 1,5-2,49 mm; d3 berdiameter 2,5-3,49 mm; d4 berdiameter 3,5-4,5 $\mathrm{mm}$ dan $\mathrm{d} 5$ berdiameter $>4,5 \mathrm{~mm}$. Selain itu dilakukan perhitungan koefisien perpindahan massa keseluruhan untuk masing-masing kelompok ukuran tetesan menggunakan gabungan korelasi model Handlos-Baron (HB) dan GarnerFoord-Tayeban (GFT) yang memerlukan data kesetimbangan dan laju alir sistem serta data hasil pengukuran konsentrasi MEK dalam nheksan di aliran masuk dan keluar kolom yang dianalisis dengan menggunakan Gas Chromatography (Nababan, 2006; Ariono dan Mirwan, 2008; Mirwan dan Ariono, 2009; Kumar dan Harland, 1996).

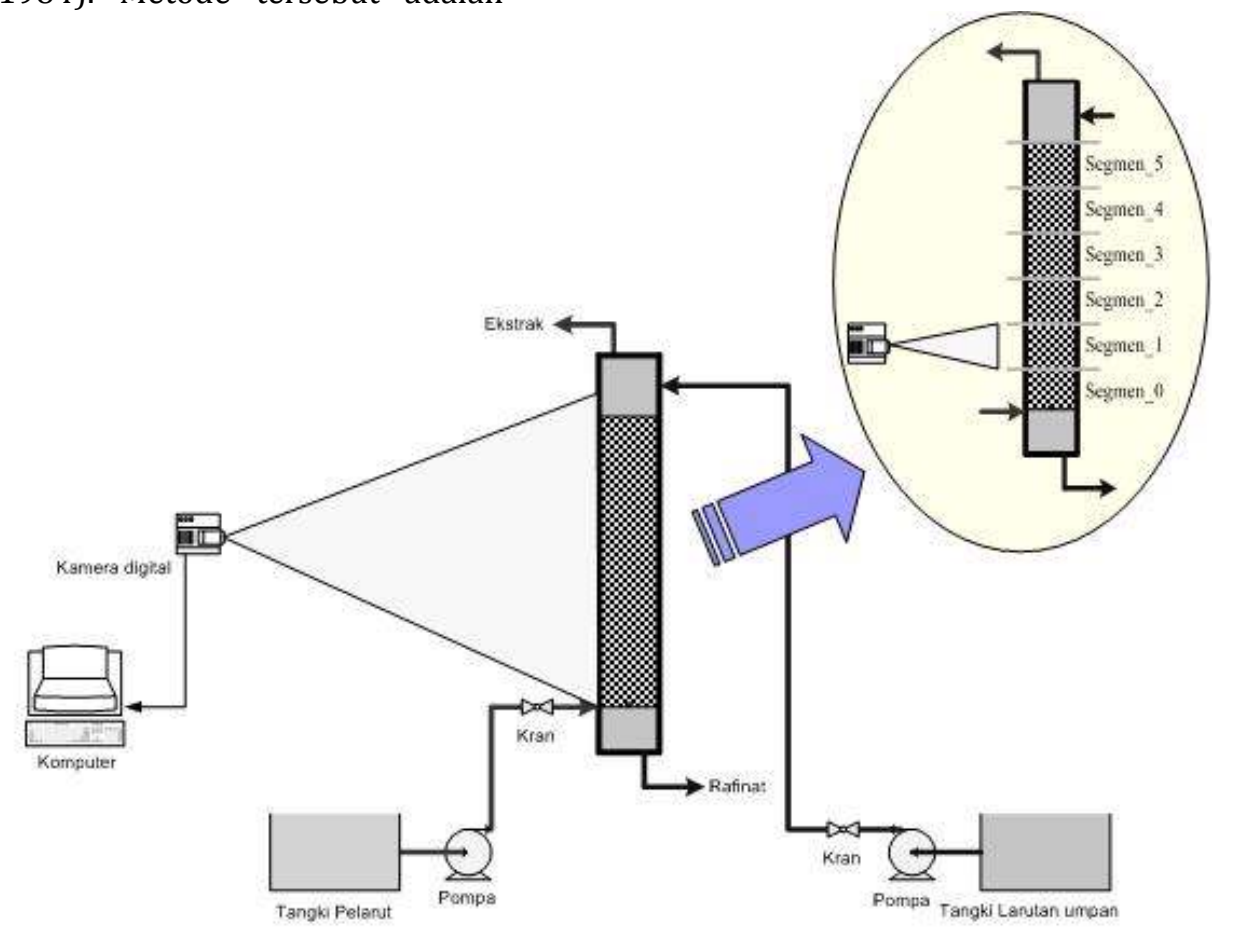

Gambar 1. Perangkat eksperimen ekstraksi cair-cair dalam kolom isian 


\section{Hasil dan Pembahasan}

Pada tiap variasi pengamatan akan diperoleh 17 (tujuh belas) kurva distribusi ukuran tetes yaitu untuk dimasing-masing segmen ketinggian yang dalam hal ini disimbolkan dengan Z0 hingga Z5. Segmen ketinggian paling bawah adalah Z0, segmen di atasnya adalah Z1 dan seterusnya hingga Z5. Dan 3 (tiga) kurva koefisien perpindahanmassa keseluruhan untuk masing-masing laju fase kontinu. Gambar 2 sampai 10 merupakan hasil pengamatan dinamika tetes dalam kolom berisi bola kaca pada tiga variasi laju alir fase kontinu dan tiga variasi laju alir fase dispersi. Gambar 11 sampai 19 adalah hasil pengamatan dalam kolom berisi raschig ring.

Gambar 2 sampai 10 menunjukkan pada rentang laju fase kontinu dan rentang laju fase dispersi yang diamati, tetesan cenderung mengecil dengan makin jauhnya dari nosel tempat tetesan terbentuk. Hal ini menunjukkan bahwa tetesan yang bergerak disela-sela isian bola padat cenderung pecah, walaupun ada juga tetesan yang bergabung menjadi ukuran yang lebih besar. Namun jumlah tetesan yang pecah jauh lebih banyak dibandingkan dengan yang bergabung (Mirwan dan Ariono, 2009; Putranto, 2004; Kumar dan Harland, 1996).

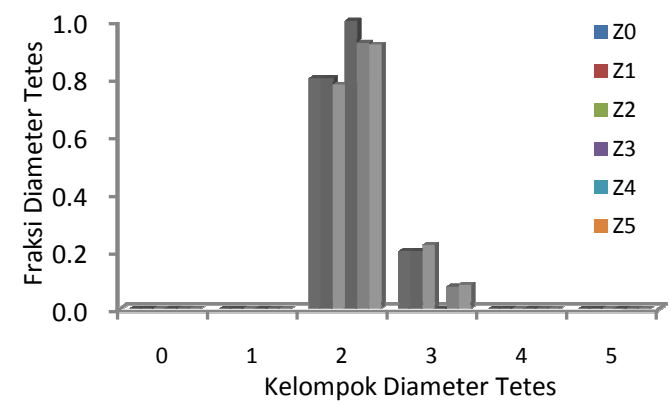

Gambar 2. Distribusi ukuran tetes dengan jenis isian bola padat, pada Qc-1 dan Qd-1

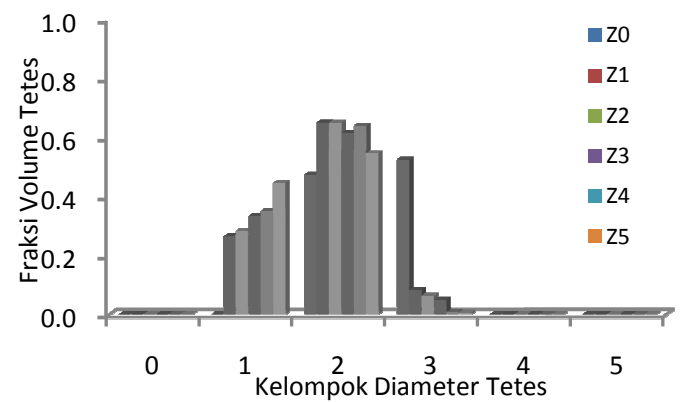

Gambar 3. Distribusi ukuran tetes dengan jenis isian bola padat, pada Qc-1 dan Qd-2

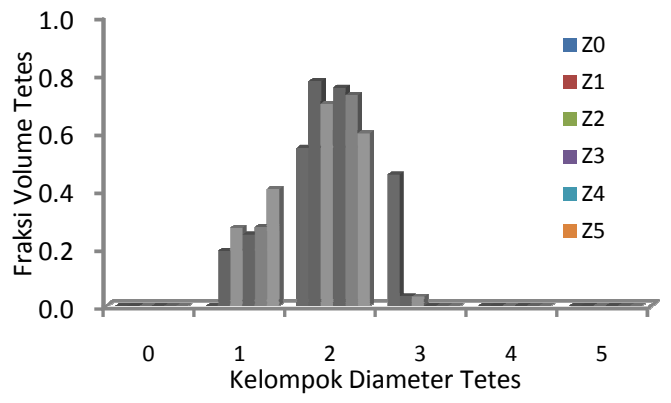

Gambar 4. Distribusi ukuran tetes dengan jenis isian bola padat, pada Qc-1 dan Qd-3

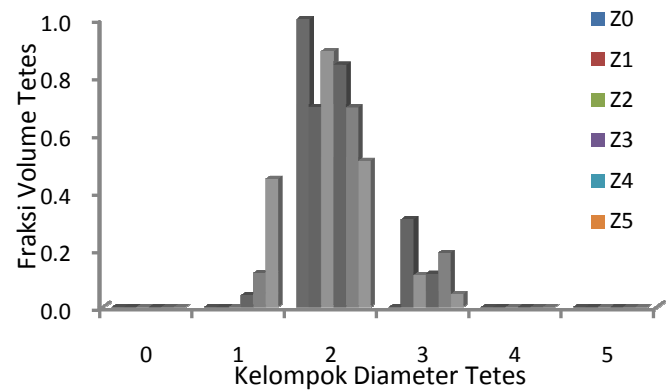

Gambar 5. Distribusi ukuran tetes dengan jenis isian bola padat, pada Qc-2 dan Qd-1

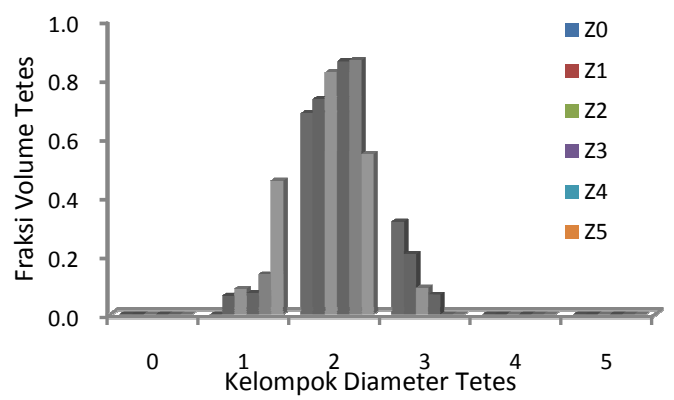

Gambar 6. Distribusi ukuran tetes dengan jenis isian bola padat, pada Qc-2 dan Qd-2.

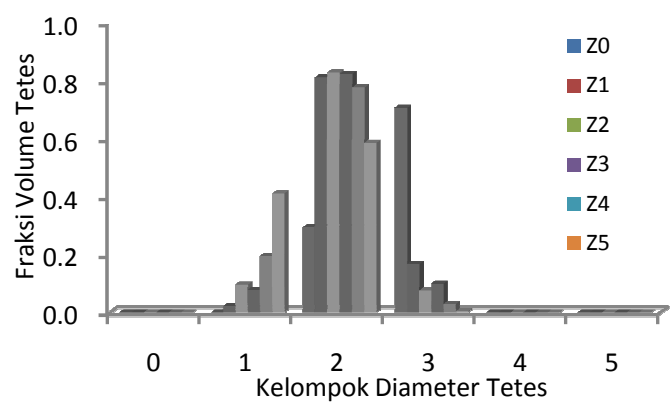

Gambar 7. Distribusi ukuran tetes dengan jenis isian bola padat, pada Qc-2 dan Qd-3

Berdasarkan pengamatan visual, pecahnya tetesan disebabkan adanya pergesekan antara permukaan isian dengan tetesan yang melintas disela-selanya sehingga 
tetesan pecah menjadi tetesan yang ukurannya lebih kecil (Putranto, 2004). Kenaikan laju alir fase dispersi memberi pengaruh makin kecilnya ukuran tetes, namun menuju ke kelompok diameter d1 (rentang ukuran 0,5-1,49 $\mathrm{mm}$ ) dan d2 (rentang ukuran 1,5-2,49 $\mathrm{mm}$ ) dengan simpangan baku dari $0,05 \%$ sampai $0,45 \%$. Dalam hal ini, tetesan pada kelompok diameter d2 sulit mengalami peristiwa perpecahan. Pada kelompok d2, gesekan tetes dengan dinding isian makin berkurang sehingga sebagian besar tetes hanya melintas disela-sela isian tanpa ada perubahan ukuran yang berarti.

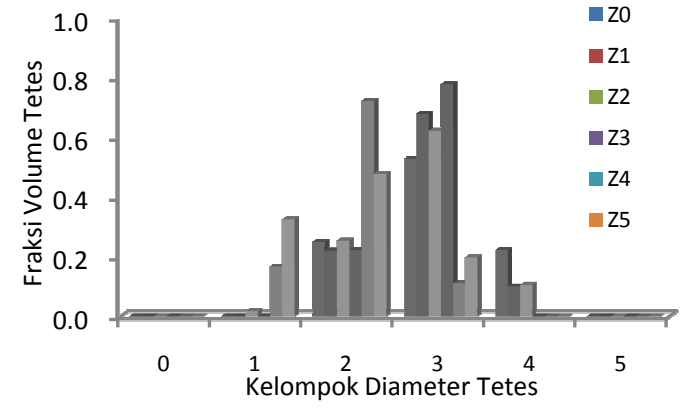

Gambar 8. Distribusi ukuran tetes dengan jenis isian bola padat, pada Qc-3 dan Qd-1

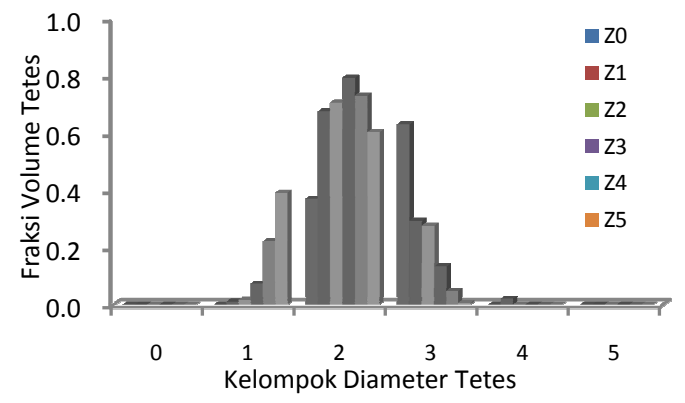

Gambar 9. Distribusi ukuran tetes dengan jenis isian bola padat, pada Qc-3 dan Qd-2

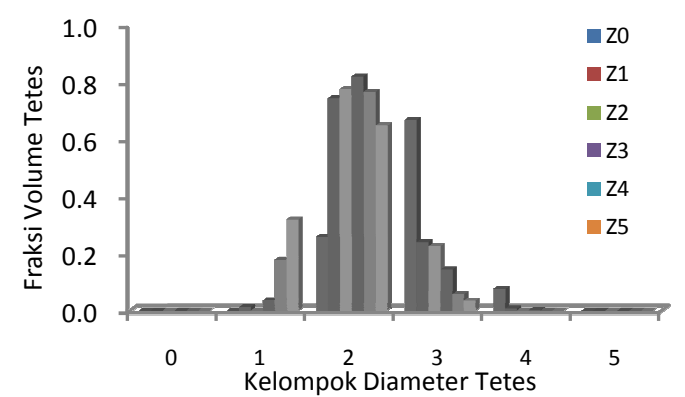

Gambar 10. Distribusi ukuran tetes dengan jenis isian bola padat, pada Qc-3 dan Qd-3

Gambar 11 sampai 19 secara keseluruhan juga menunjukkan perilaku tetesan yang sama dengan yang terjadi pada jenis isian bola padat dimana ukuran diameter tetesan menjadi lebih kecil pada segmen ketinggian yang makin jauh dari nosel tempat tetes terbentuk. Namun distribusi ukuran tetesan pada isian raschig ring lebih menyebar dibandingkan dengan pada isian bola padat.

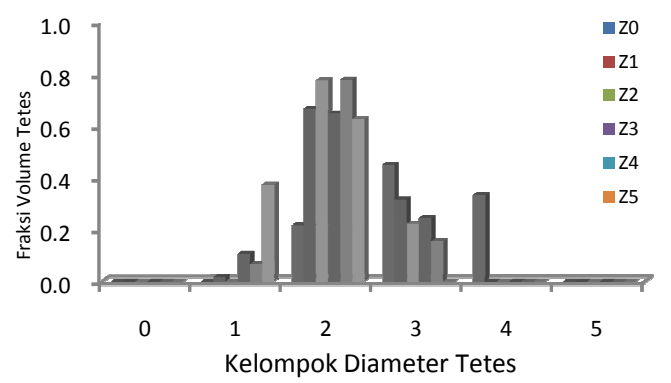

Gambar 11. Distribusi ukuran tetes dengan jenis isian raschig ring, pada Qc-1 dan Qd-1

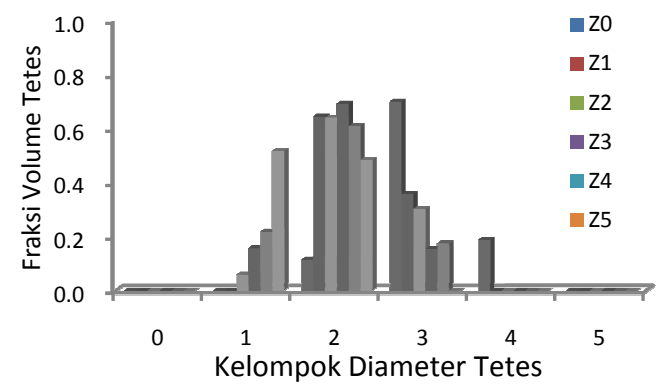

Gambar 12. Distribusi ukuran tetes dengan jenis isian raschig ring, pada Qc-1 dan Qd-2

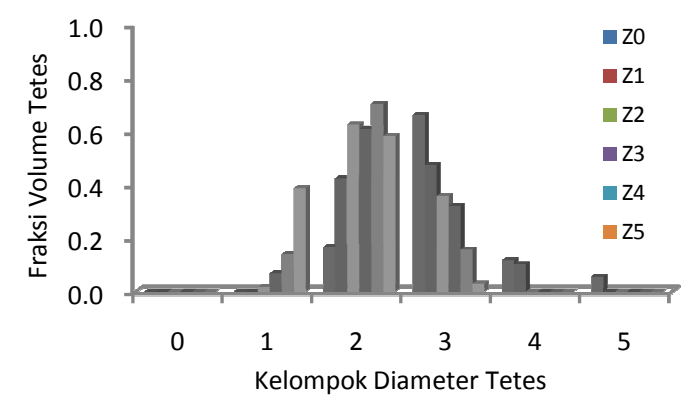

Gambar 13. Distribusi ukuran tetes dengan jenis isian raschig ring, pada Qc-1 dan Qd-3

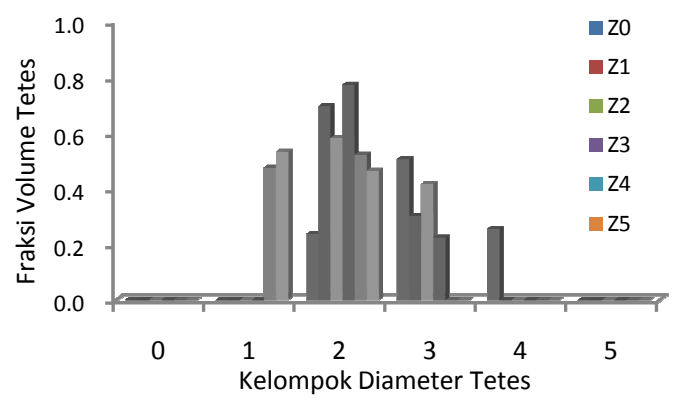

Gambar 14. Distribusi ukuran tetes dengan jenis isian raschig ring, pada Qc-2 dan Qd-1 
Walaupun distribusinya menyebar, kenaikan laju fase kontinu dan laju fase dispersi juga cenderung menuju ukuran tetes pada kelompok d1 (rentang ukuran 0,5-1,49 mm) dan $\mathrm{d} 2$ (rentang ukuran 1,5-2,49 $\mathrm{mm}$ ) dengan simpangan baku dari $0,20 \%$ sampai $1,60 \%$.

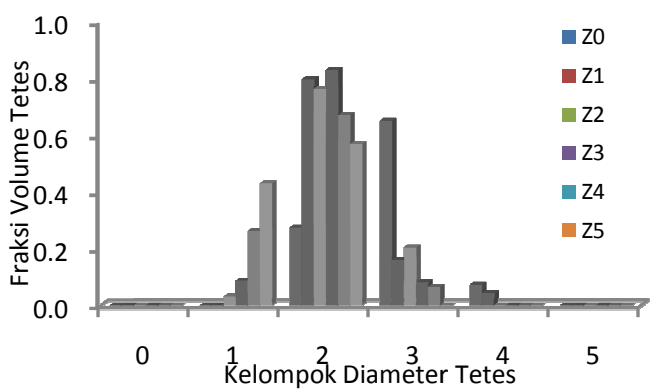

Gambar 15. Distribusi ukuran tetes dengan jenis isian raschig ring, pada Qc-2 dan Qd-2

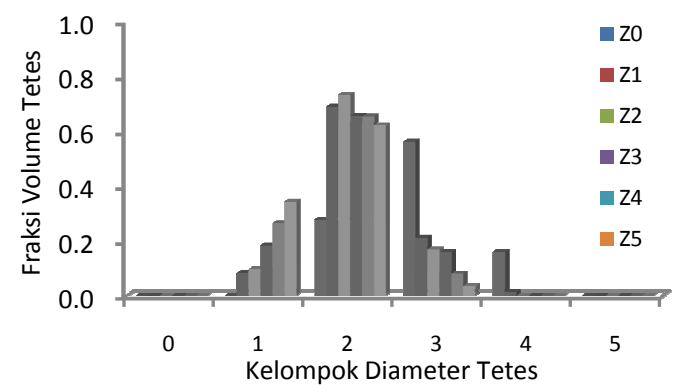

Gambar 16. Distribusi ukuran tetes dengan jenis isian raschig ring, pada Qc-2 dan Qd-3

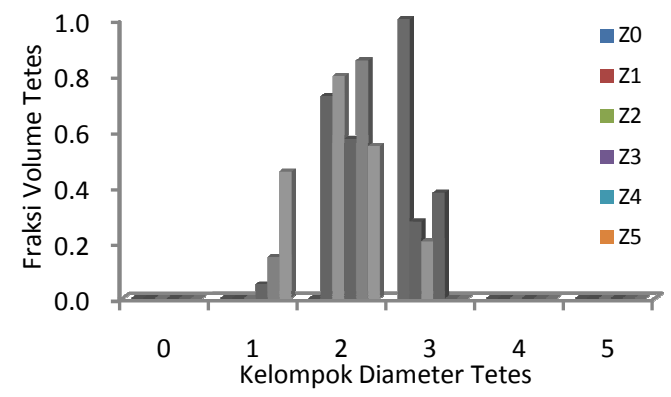

Gambar 17. Distribusi ukuran tetes dengan jenis isian raschig ring, pada Qc-3 dan Qd-1

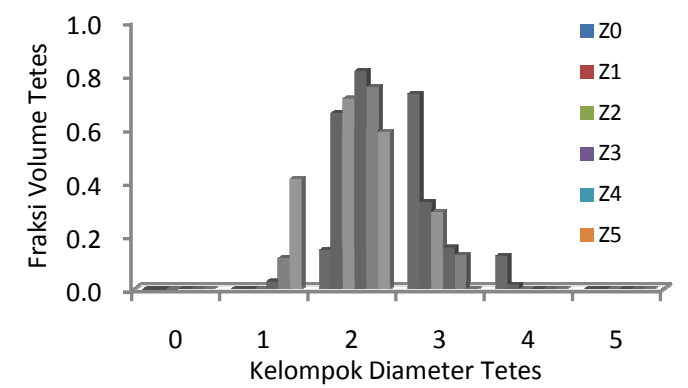

Gambar 18. Distribusi ukuran tetes dengan jenis isian raschig ring, pada Qc-3 dan Qd-2

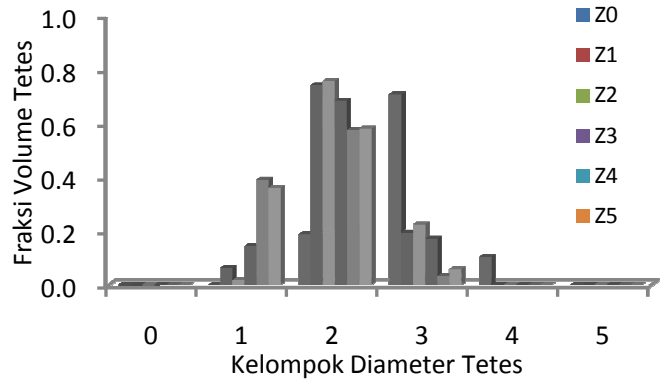

Gambar 19. Distribusi ukuran tetes dengan jenis isian raschig ring, pada Qc-3 dan Qd-3

Gambar 20 sampai 22 menunjukkan bahwa adanya pengaruh laju alir fase kontinu dan laju fase dispersi serta jenis isian terhadap laju perpindahan massa yang dinyatakan dengan koefisien perpindahan massa keseluruhan. Hal ini ditunjukan koefisien perpindahan massa yang besar terjadi pada kelompok ukuran diameter tetesan yang kecil.

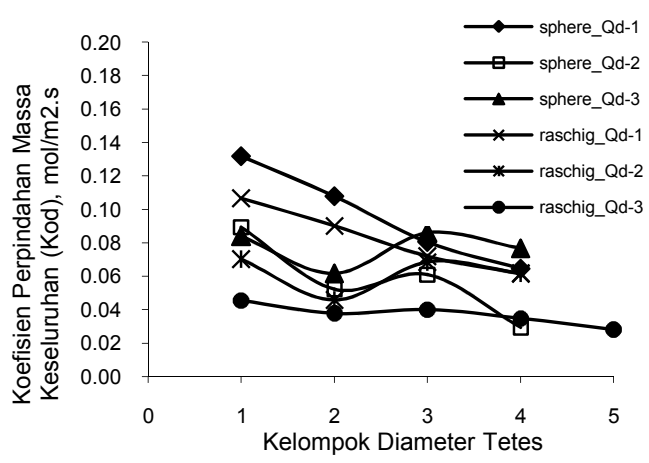

Gambar 20. Hubungan koefisien perpindahan massa keseluruhan dengan kelompok diameter pada Qc-1

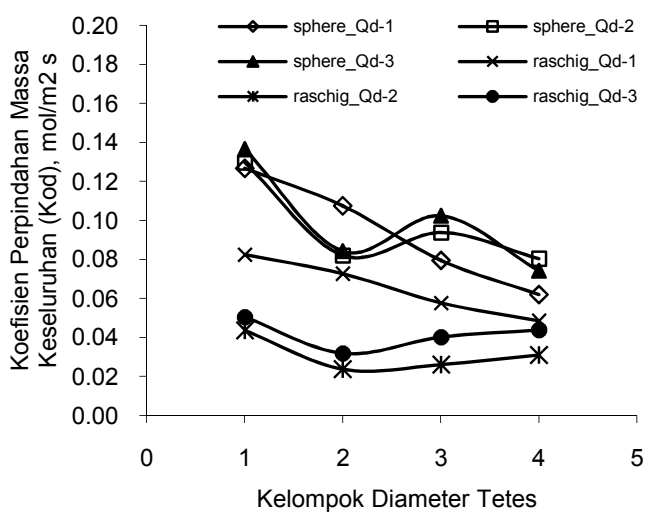

Gambar 21. Hubungan koefisien perpindahan massa keseluruhan dengan kelompok diameter pada Qc-2 


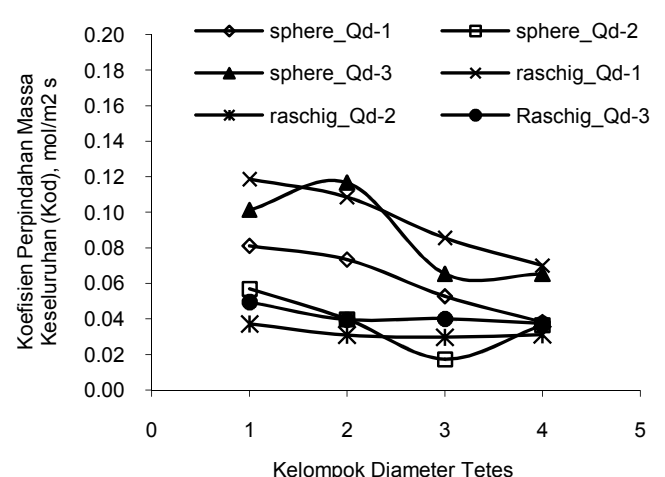

Gambar 22. Hubungan koefisien perpindahan massa keseluruhan dengan kelompok diameter pada Qc-3.

Sedangkan pada kolompok diameter tetesan yang makin besar menyebabkan harga koefisien perpindahan massa keseluruhannya mengecil. Pengecilan ukuran tetesan akan menghasilkan peningkatan harga koefisien perpindahan massa keseluruhannya, akibat makin tingginya turbulensi tetesan (Hashem dan El-Bassuoni, 2007; Slater dkk., 1988).

\section{Kesimpulan}

Dari eksperimen yang telah dilakukan dapat diambil beberapa kesimpulan. Jenis isian, laju alir fase kontinu dan laju alir fase dispersi (Qd) memberikan pengaruh yang signifikan pada perubahan bentuk ukuran atau diameter tetesan di tiap segmen ketinggian kolom. Ukuran diameter tetesan yang kecil dengan jumlah yang banyak menyebabkan kenaikan yang signifikan pada proses perpindahan massa yang dinyatakan dengan koefisien perpindahan massa keseluruhan.

\section{Daftar Pustaka}

Ariono, D.; Mirwan, A., Dinamika Tetes dan Koefisien Pindah Massa Pada Ekstraksi CairCair Dalam Kolom Isian, Prosiding Seminar Nasional Rekayasa Kimia \& Proses, 2008, A096, Semarang, 2008.

Ariono, D.; Sasongko, D.; Kusumo, P., Dinamika Tetes Dalam Kolom Isian, Prosiding Seminar Nasional Teknik Kimia Indonesia, 2006, FPU014, Palembang, 2006.
Hamilton, J. A.; Pratt, H.R.C., Droplet Coalescence and Breakage in a Packed Liquid Extraction Column, AIChe Journal, 1984, Vol. 30(3), 442-450.

Hashem, M.A.; El-Bassuoni, A. A., Drop Formation Mass Transfer Coefficients in Extraction Columns, Theoretical Foundations of Chemical Engineering, 2007, Vol. 41(5), 530-535.

Kumar, A.; Harland, S., Unified Correlations for Prediction of Drop Size in Liquid-Liquid Extraction Columns, Industrial \& Engineering Chemistry Research, 1996, Vol. 35(8), 26822695.

Laddha, G. S.; Degaleesan, T. E. , Transport Phenomena in Liquid Extraction, Tata Mc-Graw Hill Publishing Co. Ltd, New Delhi, 1976, 131145.

Mirwan, A.; Ariono, D., Dinamika Tetes Ekstraksi Cair-Cair dalam Kolom Isian dan Tanpa Isian, Prosiding Seminar Nasional Teknik Kimia Indonesia, 19-20 Oktober 2009, PP002, Bandung, 2009.

Nababan, R. F., Penerapan Model HB-GFT Proses Ekstraksi Cair-Cair Sistem MEK - Air n-Heksan Dalam Kolom Isian, Tugas Akhir Sarjana, Program Studi Teknik Kimia, Institut Teknologi Bandung, Bandung, Indonesia, 2006.

Putranto, A.; Kajian Hidrodinamika Ekstraksi Cair-Cair Pada Kolom Isian, Tesis Program Magister, Program Studi Teknik Kimia, Fakultas Teknologi Industri, Institut Teknologi Bandung, Indonesia, 2004.

Seibert, A. F.; Fair, J. R., Hydrodynamics and Mass Transfer in Spray and Packed LiquidLiquid Extraction Columns, Industrial \& Engineering Chemistry Research, 1988, Vol. 27(3), 470-481.

Slater, M. J.; Baird, M.H.I.; Liang, T.B., Drop Phase Mass Transfer Coefficients For LiquidLiquid System And The Influence of Packing, Chemical Engineering Science, 1988, Vol. 43(2), 233-245. 